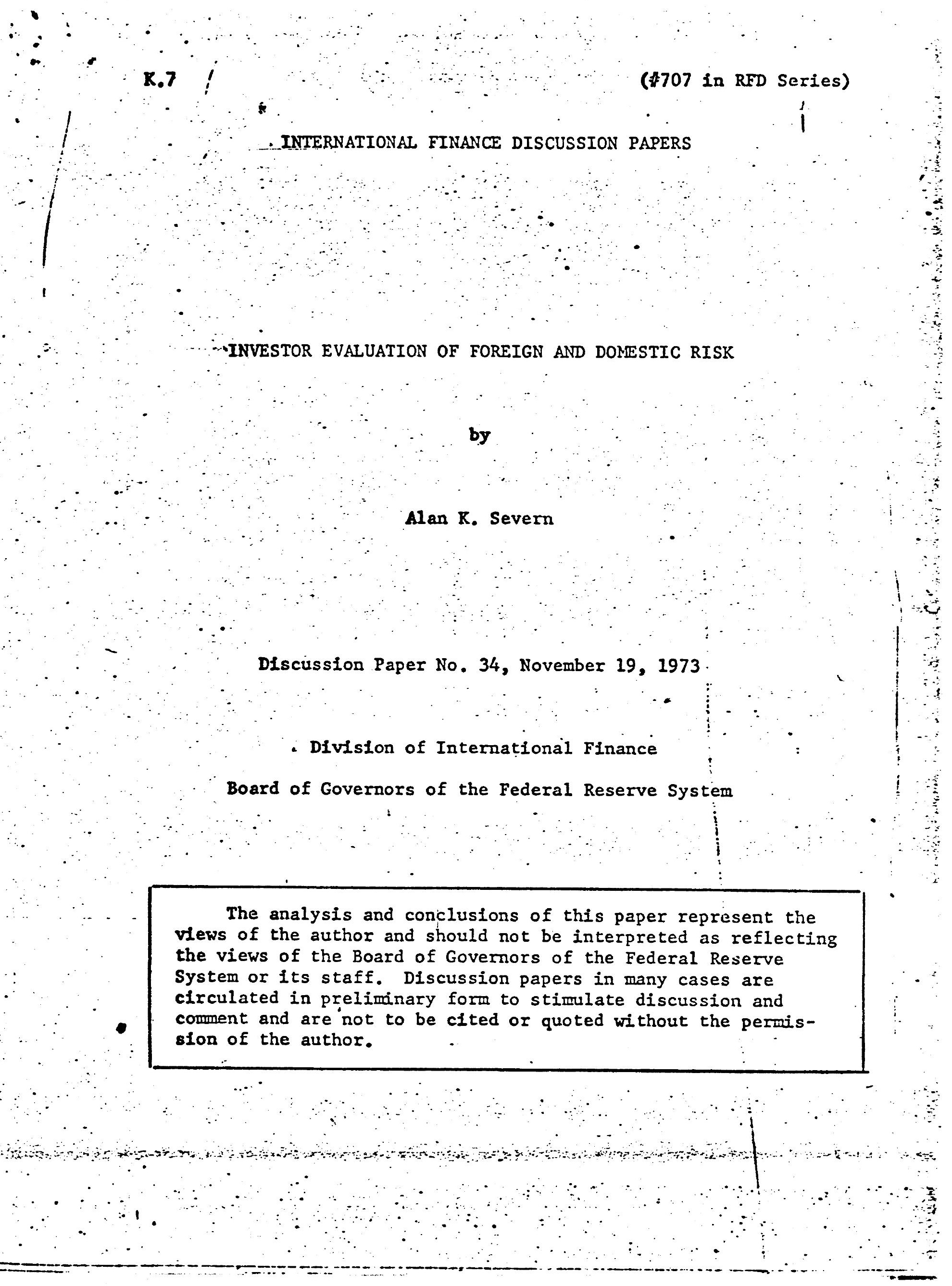




\section{INVESTOR EVALUATION OF FOREIGN AND DONESTIC RISK}

\section{$\because \quad$ Alan K. Severn*}

In recent years, foreign direct investment by U.S. manufacturing firms has grown rapidly, oriented largely toward markets outside the U.S. ${ }^{1}$ Levels of economic activity in these markets are less than $\cdots$ - Ferfectly correlated with levels in the U.S. ${ }^{2}$ From 1963 on, the U.S.

Interest Equalization Tax effectively prevented U.S. portfolio investors

from achieving international portfolio diversification directly. Given

this constraint, international diversification by firms was of benefit

to their owners, by.reducing portfolio risk for a given rate of return. ${ }^{3}$

In this paper I present an empirical test of investor response

to the respective risks associated with the foreign and domestic income

of U.S.-based direct investors. I then estimate the reduction in shaxeholder risk associated with direct investment.

The theory of capital asset pricing states that the equilibrium return on the $i^{\text {th }}$ asset is a function of its systematic risk:

$$
\bar{R}_{i}=r^{*}+\left(\bar{R}_{m}-r^{*}\right) \beta_{i}, \ldots
$$

*The author is an Economist, Board of Governors of the Federal Reserve System. He wishes to thank Martin M. Laurence for helpful comments and Cora Flaifel for programing assistance. He retains sole responsibility for opinions expressed.

ISee R.D. Belli, "Sales of Foreign Affiliates of U.S. Firms, 196165, 1967, and 1968," Survey of Current Business, October, 1970, p. 20.

${ }^{2}$ See, for example, Fred B. Ruckdeschel, "The Determinants of a Direct Investment Outflow with Emphasis on the Supply of Funds," Federal Reserve Board Staff Study No. 78, 1973, P. 119.

3 By contrast, conglomerate mergers did not reduce portfolio risk, since corporate diversification merely replaced investor diversification. See H. Levy and M. Sarnat, "Diversification, Portfolio Analys is and the Uneasy Case for Conglomerate Mergers," Journal of Finance, 25 (Sept., 1970), 795-802. 
where $\beta=p_{i n} \sigma_{i} / \sigma_{m}, \bar{R}_{m}$ is the equilibrium rate of return in the market, and $r *$ is the "riskless rate of return. ${ }^{4}$ Application of this theory to comon stocks requires recognition of market imperfections which cause the earnings of some firms to grow faster than would be expected

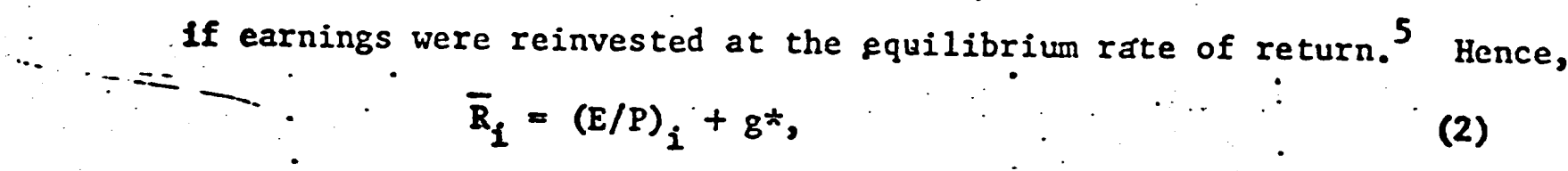

where $g^{*}$ is the excess of firm i's growth rate over that which would be expected if it had no opportunity for investment in assets yielding more than $\bar{R}_{m}$. Therefore, the equilibrium capitalization rate applied to a firm's current earnings is:

$$
\therefore \quad(E / P)_{i}=r^{*}+\left(\bar{R}_{m}-r^{*}\right) \beta_{i}-\left(g-b \bar{R}_{m}\right) \text {, }
$$

where $b$ is the proportion of earnings retained. 6

Systematic risk of the firm's earnings, $\beta_{i}$, is calculated from deviations around the growth rate of earnings per share during the calculation period, in relation to the earnings per share of the Standard and Poor Composite Index. Earnings are used directly to

${ }^{4}$ See J. Lintner, "The Valuation of Risk Assets and the Selection of Risky Assets in Stock Portfolios and Capital Budgets," Review of Economics and Statistics 47 (February, 1965), 13-37, and W.F. Sharpe, "Capital Asset Prices: A Theory of Market Equilibrium Under Conditions of Risk," Journal of Finance 19 (September, 1964), 425-442.

5 Such opportunities for above-normal growth are especially prevalent among the direct investors under consideration here, because accumulated research and development establishes barriers to entry to the industries in which direct investors are located. See A.K: Severn and M.M. Laurence, "Direct Investment, Research Intensity, and Profitability," Journal of Financial and Quantitative Analysis 8 (March, 1974), forthcoming.

\section{6}

The observed growth rate, $g$, is adjușted by retentions times $\bar{R}_{\text {pither }}$, rathan $\bar{R}_{i}$, since the risk differential of the $i$ th firm is already accounted for by $\beta_{i}$, which incorporates fluctuations around the above-normal rate of return and hence in $g$. 


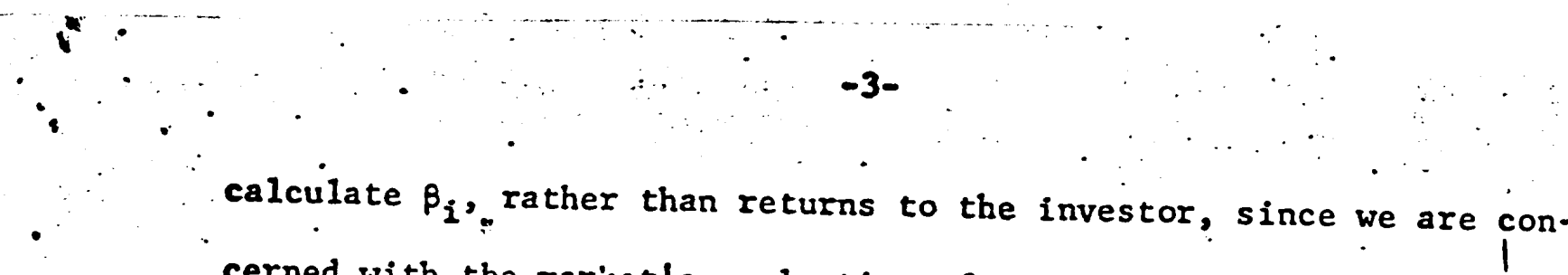
cerned with the maricet's evaluation of earnings. Earnings per share, in each year, are normalized by their geonetric mean for the calculation period. 7

Systematic risk of foreign (domestic). earnings is obtained by muitiplying deviations of earnings, as described above, by the trend value of the ratio of foreign (domestic) to total earnings. Hence, the sum of foreign and domestic risk is constrained to equal the systematic risk of the firm as a whole.

Earnings-price ratio is reported earnings per share, averaged over two years, divided by share price at the end of the first of the two years. Thus, investors are assumed to forecast accurately the firm's earnings in the second year. 8

Past growth of earnings cannot be taken as a proxy for expected future growth of earnings. 9 Past growth of book valye cannot be used

7 The ratio of earnings to book value has been used as an alternative to this normalization and calculation of trend. See R.H. Litzenberger and A.P. Budd, "Corporate Investment Criteria and the Valuation of Risk Assets," Journal of Financial and Quantitative Analvsis 4 (Dec., 1970), 395-419. But their procedure builds in an errors-in-variables bias, because of divergences between earnings power and book value. While the more complicated procedure used in this paper was necessary because data on book value of foreign (domestic) operations are generally not available, it gives far superior results for the firm as a whole than does risk calculated from the ratio of earnings to book value.

${ }^{8}$ Preliminary tests indicated that use of a single year's earnings gave poorer results than the average of earnings of the cross-sectional - year and the following year. The dependent variable used in this study inplies perfect forecasting, by investors, of earnings of the following year. Use of a given year's earnings, divided by price at the end of the year implies zero forecasting by investors. All that is asserted here is that perfect forecasting is closer to reality than zero fore-
casting ability.

${ }^{9}$ See J. Iintner and R. Glauber, "Higgledy Piggledy Growth in America," in J. Loric and R. Brealey, eds., Modern Developments in

- Investment Management (New York: Praeger: 1972), 645-662. 


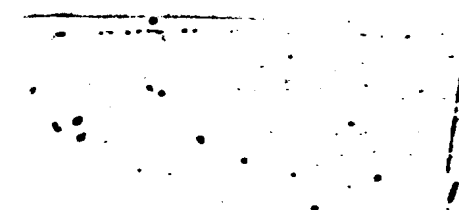

since, in the absence of new equity financing, it is determined only

by retained earnings. Given retained earnings and therefore book

value, the firm can either increase assets or reduce liabilities.

Growth is equal to the return on assets times the retention rate.

The firm with unusually profitable investment opportunities should

have a high rate of investment, rather than using transitory income

to reduce liabilities. Therefore I use past growth of assets as a

proxy for expected future growth of earnings.

The market return, $\bar{R}_{m}$, is calculated as the sum of the cividend

yield and the growth rate of dividends (from 1956 through the last

year of the calculation period). The riskless rate was taken as the

market yield on 9-to-12 month Treasury bills, since $\beta$ is based on

amnual, rather than quarterly, fluctuations in earnings. 10

Data were available for two cross-sectional years, 1965 and 1966.11

Three firms were eliminated from the original sample of 63 because

of negative earnings in at least one year. Preliminary tests showed

that a uniform computation period of seven years was unworkable,

because the 1960-61 recession caused "cyclical" and "growth" firms

to have similar values of $\beta$. Therefore. a. computation period of eight

years (1959-66) was used for the 1966 cross section, and seven years

10 Risk which is measured from annual data is not the same risk as that which is measured fron shorter periods. See H.E. Phillips and J.P. Seagle, "Data: A Blessing or a Curse in Portfolio Selection," Proceedings of the Fifth Annual Yeeting of the American Institute for Decision Sciences.

11. The data were originally developed for the study reported in A.R. Severn, "Investment and Financial Behavior of American Direct Investors in Manufacturing," Universities - "iational Dureau Conferance on Intcrnaticnal Mobility and Yovement of Canital (Viev York: Columbia University Press, 19i2), 367-39ó. 


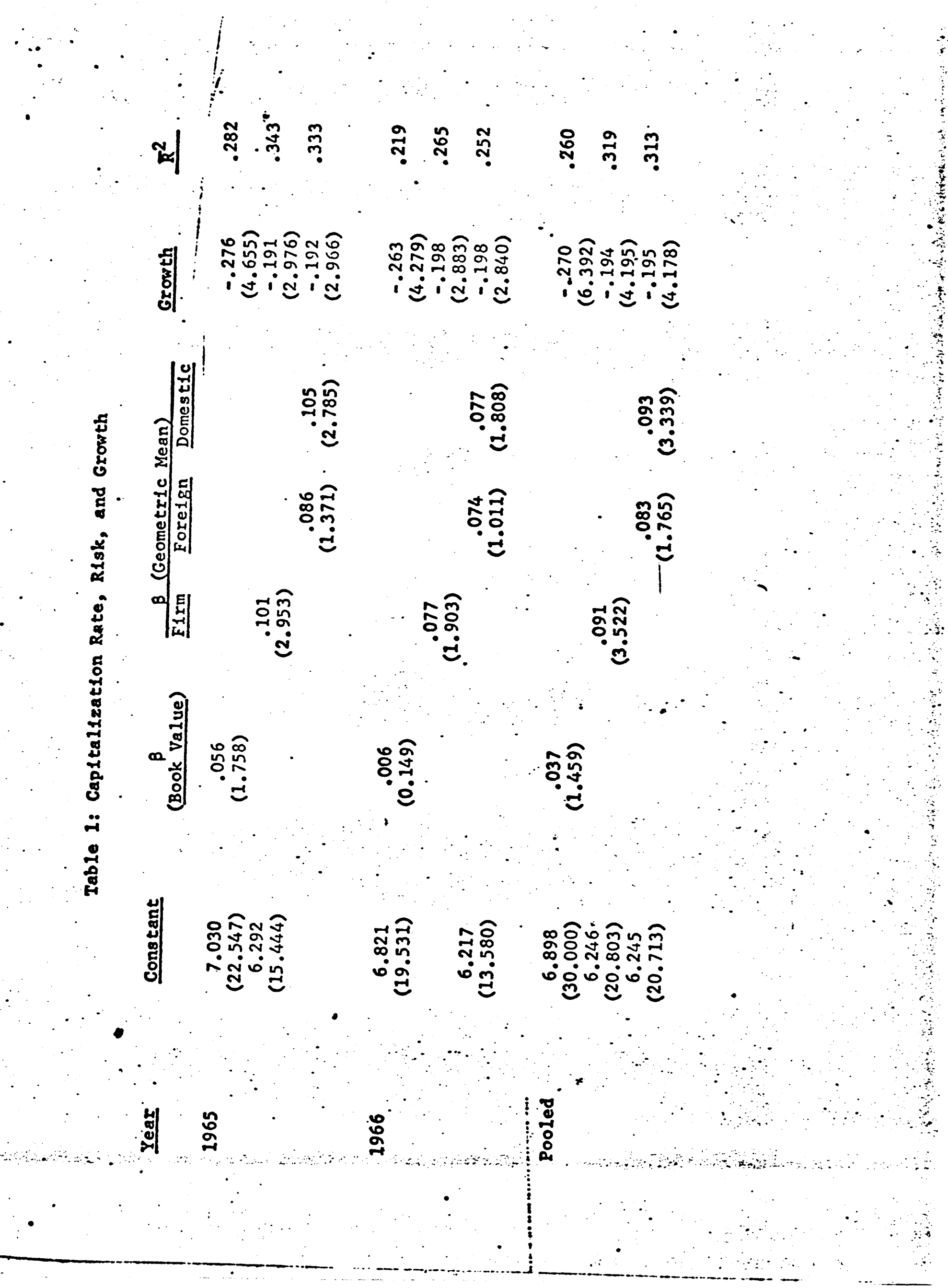


for the 1965 cfoss section.

The results (Table 1) show that the estimated effect of foreign and domestic risk is similar. Since the results were stable from one year to the other, the two cross sections were pooled. 12 The cocfficients. of foreign and domestic risk show no evidence that investors discounted foreign risk to a greater degree than domestic risk, despite the unrealized potential for expropriation, currency restrictions, or devaluations greater than warranted by relative prices.

The fact that the estimated coefficients are significantly below the unitary effect predicted by the theory comes about for two reasons. First, the estimated risk premium, $\left(\bar{R}_{\mathfrak{m}}-r^{*}\right)$, is larger than that used in other studies. 13 Second, investors are likely to perceive

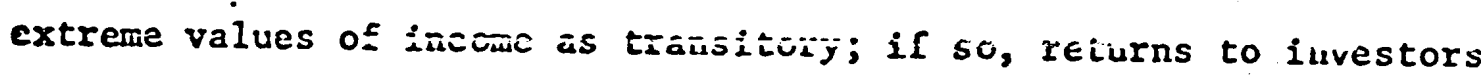
vill have smaller variation than will earnings. Hence, there would be less-than-unitary reaction to income risk, even if there is unitary reaction to investor risk.

The coefficient of growth falls as the estimate of risk improves, suggesting that growth itself may be overrated when risk is not taken into account. 14

12 The Chow test gave a value of $F$ of .196, relative to the $5 \%$ level of 2.68. Hence, there is no evidence that pooling is not legitimate.

I3 R.H. Litzenberger and A.P. Budd, "Corporate Investment Criteria," used the market earnings-price ratio to represent $\bar{R}_{m}$; hence, they failed to allow for inflation and for above-normal growth by some firms in the market average, and thereby imparted an upward bias to their estimate of the coefficient of risk.

${ }^{14}$ In both samples, growth and risk were inversely correlated. 
Therefore; I assume that investors discount foreign and domestic risk equally, and. estimate the reduction in total risk resulting from International diversification on the part of U.S. firms. The major drawback to such an estimation is that the proportion of foreign to total earnings, $W$, must be taken as given. By contrast, maximization of shareholder wealth should have led firms to require a lower rate of return on foreign investment than on domestic investment (at least after the IET was imposed). 15 If so, any estimate of risk reduction represents an upper limit to the improvement in shareholder wealth. Within the limits of taking $\dot{W}$ as given, risk reduction can be measured in terms of how much larger the firm's total risk would have been if foreign income had involved the same risk as domestic income. Based on sample means, total risk was 1 ower by $.0088 \%$ in $1959-65$ and $.0113 \%$ in 1966, for each $1 \%$ of the firm's total earnings arising from foreign, rather than domestic, investment. Given the risk coefficients of Table 1 and the risk premia on which they are based, these estimates imply that the capitalization rate $(E / P)$ was lower by $.0038 \%$ at the beginning of 1965 and $.0031 \%$ at the beginning of 1966, for each $1 \%$ of total income which was earned abroad.

The sample mean of $W$ was $2 \%$. Hence, a typical firm in my sample was accorded a capitalization rate about ten basis points lower than what it would have had if all income had been subject to the degree of risk which it experlenced domestically.

15 In addition, there is indeterminacy (etonomic as well as accounting) in the allocation of earnings to foreign vs. domestic operations, because of joint costs and transfer pricing. Furthermore, exports make possible some amount of foraign income even in the
absence of forcign investment. 
To this point, I have discussed the risk-reducing aspect of forelgn investment in terms of the firm's maximizing the net worth of Its shareholders. Undoubtedly, the relatively high rate of growth of foreign investment of the $1960^{\circ} \mathrm{s}$, increased share prices of direct investors, as their capitalization rates fell relative to those of domestically-oriented firms. At the same time, part of the increase in direct investment was probably a response by firms to the low systematic risk of foreign income (relative to fluctuations of eamings in the U.S.). After the Interest Equalization Tax was Imposed in 1963, investment in shares of direct investors was the only means by which U.S. portfolio investors could diversify away part of the risk of U.S. earnings. Hence, the relatively low capitalization rate of foreign earnings may have stimulated direct Investment, thereby providing a partial offset to the gross balance of payments improvement brought about by the IET.

For this and other reasons, U.S. balance-of-payments deficits subsequent to the imposition of the IET brought about the mandatory Forelgn Direct Investment Program (FDIP) at the beginning of 1968. After 1968, the FDIP had 1ittle effect on the amount of direct investment by U.S. manfacturing firms. 16 Rather, it forced U.S. firms to obtain part of their funds for direct investment abroad, at rates generally above those in the U.S ${ }_{\bullet}^{17}$ Therefore it offset all or part

16 See G. Stevens, "Capital Mobility and the International Firm," in F Machlup, et al, eds, International Mobility of Capital, p. 342. 1 See A. Severn, "The Financing of the Nulti-National Firm: Comment, "kyklos 26 (1973), forthcoming. 


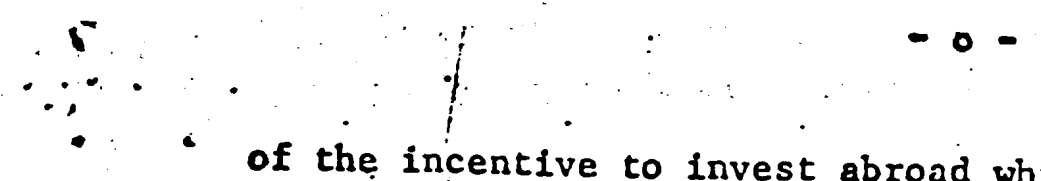

of the incentive to invest abroad which was provided when the IET effectiveIy prevented." International diversification by U.S. Investors.

Reduction of risk by means of direct investment should also affect allocation of investment funds within the U.S. Horizontal direct investment involves the exploitation of some resource, within the firm, which is not readily sold to a foreign-owned firm. The best example of such a resource is the results of research and development activity. Therefore the lower capitalization rate accorded to direct investors should foster investment in research and development, relative to other forms of investment which are intended for domestic use only. The rising ratio of company-funded research and development expenditures to sales, during the sample period considered here, supports this contention. 19

Viewed in this light, rist roductinn ky means of direct investment should remain relevant even after the planned termination of the IET in 1974 brings about a greater degree of perfection in International capital markets. To the extent that implementation of the results of research activity continues tc motivate direct Investment, risk reduction within the multinational firm will continue to benefit welfare, by reducing the risk associated with research activity. At the same time, any increase in international economic integration will limit the degree to which risk can be reduced by foreign direct investment.

- 18

- See R. E. Caves, "International Corporations: The Industrial Economics of Foreign. Investment," Economics NS 38 (1971), 1-27 19 That is, the high profitability of research and development is - supplemented by relatively low risk in its application. Sec A. Severn and M. Lawrence, "Direct Investment, Research Intensity,
and Profitability." 